University of Michigan Law School

University of Michigan Law School Scholarship Repository

1918

\title{
Effectiveness of Oral Contracts, Within the Statute of Frauds
}

John B. Waite

University of Michigan Law School

Available at: https://repository.law.umich.edu/articles/902

Follow this and additional works at: https://repository.law.umich.edu/articles

Part of the Contracts Commons

\section{Recommended Citation}

Waite, John B. "Effectiveness of Oral Contracts, Within the Statute of Frauds." Mich. L. Rev. 16, no. 8 (1918): 624-7.

This Response or Comment is brought to you for free and open access by the Faculty Scholarship at University of Michigan Law School Scholarship Repository. It has been accepted for inclusion in Articles by an authorized administrator of University of Michigan Law School Scholarship Repository. For more information, please contact mlaw.repository@umich.edu. 
Effectiveness of Orai Contracts, Within the Statute of Frauds.In Morris v. Baron and Co., (House of Lords, IgI7), 87 L. J. R. (K. B.) I45, plaintiff and defendant had entered into a contract of sale and plaintiff, as vendor, had delivered part of the goods agreed upon. Delivery of the remainder would have been a condition precedent to any recovery by the plaintiff. This contract, however, was followed by a second one, not in writing, whereby plaintiff was absolved from delivering the rest of the goods, but by which he agreed that he would deliver them if the defendant should so request. Thereafter plaintiff brought this action for the "price" of the goods delivered. The defendant set up, by way of counterclaim, plaintiff's failure to deliver the rest of the goods as requested under the second contract. The court held that the second contract, although not in writing, absolved the plaintiff from having to deliver all the goods under the first contract, and therefore allowed him to recover for the goods delivered, but that, because it was not in writing, the defendant could not maintain his counterclaim for breach of it. 
In Noble v. Ward, 35 I. J. Ex. 8I, I. R. 2 Ex. 135, the defendant had contracted to buy goods from the plaintiff and was sued for his refusal to accept and pay for them. He defended on the ground that this contract had been rescinded by a later oral one substituted for it. The court held that because the second agreement did not conform to the requirements of sec. I7 of the statute of frauds it did not have the effect, as a matter of law, of rescinding the first one. This case was interpreted in Morris v. Baron and Co. as holding, at most, only that a variation by agreement not in writing would not be recognized, and that it should have been left to the jury to say whether the parties intended by their new oral contract to rescind the prior written one. It was distinguished from the principal one on the ground that the parties did intend by their second contract to rescind the first one, and that such rescision would be effective even though not in writing.

There is much conflict in the decisions as to whether a contract within the Statute of Frauds can be varied by oral agreement as to time of performance and kindred matters. Neppach v. Oregon, etc. $R$. $R .46$ Ore. 374, 7 Ann. Cas. I035, and cases there collected, (holding that the oral extension of time will be recognized as valid when it has been acted upon, at least.) Actual rescission of a contract by oral agreement is effective, even though the contract itself be one within the Statute. Goman v. Salisbury, I Vern. 240; Proctor v. Thompson, I3 Abbott N. C. (N. Y.) 340. So also, although the authority is scant, a contract in writing as required by the Statute can be rescinded by the substitution of an oral contract, if the parties intend to rescind thereby. Goss v. Lord Nugent, 5 B. and Ad. 58 (dictum); Gilbert v. Hall, I I. J. Ch. I5 (at least in equity); Reed v. McGrew, 5 O. 376; Dearborn v. Cross, 7 Cow. (N. Y.) 48 . The court in the principal case evidently treated the second contract as evidencing an intent to abrogate the original contract.

The court also distinguished the principal case from Noble v. Ward on the ground that the statute under which that case was decided declared that a contract not in conformity with it should not be "allowed to be good," while the Sale of Goods Act, which governed Morris v. Baron and Co., provided only that it should not "be enforced by action." This at once raises the question whether there is not an intent behind the Statutes broader than their literal wording might imply. The preamble of the original Statute might lead one to suppose that its object was to do away with certain oral contracts, "For prevention of many fraudulent practices which are commonly endeavored to be upheld by Perjury and Subornation of Perjury." This is the view of the court in King v. Welcome, 5 Gray (Mass.) $4 \mathrm{I}$. The action was in quantum meruit for services rendered, and the defense was that they were rendered under an oral contract not to be performed within a year, which plaintiff had broken. Although the Massachusetts statute provided only that no action should be brought on such a contract, the court held that, "So far as it concerns the prevention of fraud and perjury, the same objection lies to the parol contract, whether used for the support of, or in defense to an action. The gist of the matter is, that, 
in a court of law and upon important interests, the party shall not avail himself of a contract resting in words only, as to which the memories of men are so imperfect, and the temptations to fraud and perjury so great." "Looking at the mere letter of the statute, the suggestion is obvious, that no action is brought upon this contract. *** The difference, it is clear, is not one of principle." Accordingly the use of the oral contract even in defense was denied. So also in Scotten v. Brozur, 4 Har. (Del.) 324, it was said, "The danger in this respect (false testimony) and the necessity of the rule which the statute prescribes, are equally strong, whether the suit is directly upon the contract, or the contract is sought to be proved incidentally and by way of defense." Acc., Bernier v. Cabot Mfg. Co., $7 \mathrm{I}$ Me. 506. $A$ vendee in possession under an oral contract of sale can not set up the contract in defense to an action of ejectment. Zeuske $\nabla$. Zeuske, 55 Ore. 65 , Ann. Cas. I912 A. 557, and cases there collected.

On the other hand, Blackstone's sole comment is that "The statute of frauds and perjuries (was) a great and necessary security to private property." Commeatraries, Bk. $4{ }^{*}$ p. 440 . If protection to property was the motivating intent of the Statute and its true justification, the distinction based on verbiage that is made in Morris v. Baron and $\mathrm{Co}$. is eminently proper. This is the view, undoubtedly, of most courts. The opinion in Gray v. Gray, 2 J. J. Marshall (Ky). 2I, thus expresses it, "The letter of the statute of frauds does not declare a parol contract for land void, it only refuses to give a remedy for the enforcement or breach of such a contract; but the contract itself may for the purpose of defense, be used as a shield to protect the defendant against unconscionable demands, and claims growing out of the contract." In accord with this doctrine, it is generally held that in a suit on the common counts a contract may be used in defense, even though it does not accord with the Statute. Philbrook v. Belknap, 6 Vt. 383; Weber v. Weber, (Ky.), 76 S. W. 507; Laffey v. Kaufman, I34 Cal. 391; McKinney v. Harvie, 28 Minn. I8; Sims v. Hutchins, 8 S. \& M. (Miss.) 328; Schechinger v. Gault, 35 Okla. 416, (even though the Statute declares it "invalid").

This is not usually the rule, however, where the statute says that such a contract is "void." Donaldson's Admr. v. Waters' Admr. 30 Ala. I75; Nelson v. Shelby Mfg. Co., 96 Ala. 515; Scott v. Bush, 26 Mich. 418; Lemon v. Randall, I24 Mich. 687; Salb v. Campbell, 65 Wis. 405 . Neither is it the rule when the defendant is himself in default under the contract. In such cases, however, the inadmissability of the contract is not due to the Statute but because the defendant's acts have rescinded it. Jackson v. Stearns, 58 Ore. 57; Booker v. Wolf, 195 Ill. 365; Burlingame v. Burlingame, 7 Cow. (N. Y.) 92; Shute v. Dorr, 5 Wend. 204 (on the double ground that it had been rescinded and that it was "void" under the N. Y. Statute); Cf. Jellison $\nabla$. Jordan, $68 \mathrm{Me}$. 373 (apparently because of the Statute). In these cases the recovery is allowed, of course, not for breach by the defendant of the oral contract, but because of his implied promise arising out of unjust enrichment. Loss sustained by the plaintiff, not resulting in enrichment of the defendant, can not be recovered. Gazzam v. Simpson, II4 Fed. 7I; 
Dowling v. McKenncy, I24 Mass. 478. It seems that contracts which do not accord with the Statute may nevertheless have an effect in showing the intent in an escrow. See supra, p. 569 ff. The fact that a contract is unenforceable because not in writing does not prevent its use to show value in actions of quasi-contract, Murphy v. De Haan, II6 Iowa 6I; contra, because "void" by statute, Sutton v. Rowley, 44 Mich. II2; or to show the amount of rent due, Evans v. Winona Lumber Co., 30 Minn. 515; Steele v. Anheuser-Busch Assn., 57 Minn. I8; or to show damage resulting from tort by a third party, Burruss v. Hines, $94 \mathrm{Va} .4 \mathrm{I} 3$; or that a settled claim had a real basis, Michels v. West, Iog IIl. App. 418; or to show reason for money paid to defendant, Coughlin v. Krowles, 7 Met. (Mass.) 57. It is unnecessary to cite authority to the effect that parties unconnected with a contract can not collaterally attack it as "void." This is true even where the defendant's liability results only from performance by plaintiff of a contract which could not have been enforced because of the Statute. Beal v. Brown, I3 Allen (Mass..) Ir4. In suit for specific performance of a written contract to sell land the defendant was allowed to show that the plaintiff had orally contracted to re-sell the land to him. Frith v. Alliance Investment Co., 49 Can. Sup. Ct. 384 , Ann. Cas. I914 D. 458 . It is also very generally held that the Statute must be affirmatively pleaded as a defense, since the contract gives a legal right until advantage is taken of the Statute. Crane v. Powell, 139 N. Y. 379; Citty v. Manufacturing Co., 93 Tenn. 276. As to the interpretation of the Statute, therefore, a statement from Evans v. Winona Lumber Co., supra, is applicable. "This rule may not be logical-very likely it is not, as an original proposition; but that it is the rule established by the authorities there can be no doubt." 